\title{
Improvement Mechanism of Work Oriented by Ergonomic Increase Health Quality and Productivity
}

\author{
Ni Putu Sri Arnita ${ }^{1 *}$, Nyoman Adiputra ${ }^{2}$, Susy Purnawati ${ }^{3}$, \\ I Nyoman Sucipta ${ }^{4}$, I Made Sutajaya ${ }^{5}$, and Luh Putu Ratna Sundari ${ }^{6}$ \\ 1) Ergonomic and Work Physiology Department, Udayana University \\ ${ }^{2,3,6)}$ Physiology Department, Faculty of Medicine, Udayana University \\ 4) Agricultural Engineering, Faculty of Agricultural Technology, Udayana University \\ 5) Biology and Marine Fishery Department, Faculty of Mathematics and Science, \\ Ganesha Education University \\ *) Correspondence e-mail: sriarnita847@yahoo.com \\ doi: https://doi.org/10.24843/JEI.2020.v06.i02.p02
}

Article Received: 07 June 2020; Accepted: 13 October 2020 Published: 31 December 2020

\begin{abstract}
The aim of this research is to reduce musculoskeletal disorders, work stress, and increase productivity of workers piranti upakara makers by work mechanism improvement using ergonomic work oriented. Through a quasi-experimental using treatment by subject design and randomized pre and post-test group design assessed: (a) improvement mechanism of work oriented by ergonomic reducing musculoskeletal disorders, was recorded by Nordic Body Map Questionnaire; (b) improvement mechanism of work oriented by ergonomic reducing work stress, was recorded by Work Stress Questionnaire; (c) improvement mechanism of work oriented by ergonomic increase the productivity of workers, assessed by output (product produced) divided by input (pulse) multiplied by time. Data collection was done at 10 (ten) days before and after working, in Period I and Period II on 14 samples. Data obtained were analyzed using paired t-test at a significance level of 5\%. The result showed that improvement mechanism of work oriented by ergonomic, reducing musculoskeletal disorders of workers to $44.45 \%$, reducing the work stress of workers to $29.90 \%$, and increasing productivity of workers to $53.93 \%$. It can be concluded that improvement mechanism of work oriented by ergonomic reducing musculoskeletal disorders, work stress, and improving productivity of workers piranti upakara makers.
\end{abstract}

Keywords: ergonomic, piranti upakara, ergonomic work mechanism

\section{Perbaikan Mekanisme Kerja Berorientasi Ergonomi Meningkatkan Kualitas Kesehatan dan Produktivitas}

\begin{abstract}
Abstrak
Penelitian ini bertujuan untuk membuktikan dan mengimplementasikan perbaikan mekanisme kerja berorientasi ergonomi mengurangi keluhan muskuloskeletal dan stres kerja serta meningkatkan produktivitas pekerja pembuat piranti upakara. Penelitian ini berupa eksperimental semu (quasi experimental) dengan rancangan sama subjek dan pola randomized pre and posttest group design, dilakukan penilaian berupa: (a) perbaikan mekanisme kerja berorientasi ergonomi mengurangi keluhan muskuloskeletal pekerja pembuat piranti upakara didata dengan kuesioner Nordic Body Map; (b) perbaikan mekanisme kerja berorientasi ergonomi mengurangi stres kerja pekerja pembuat piranti upakara didata dengan Kuesioner Stres Akibat Kerja; (c) perbaikan mekanisme kerja berorientasi ergonomi meningkatkan produktivitas pekerja pembuat piranti upakara dinilai berdasarkan output
\end{abstract}


(produk yang dihasilkan) dibagi dengan input (denyut nadi) yang dikalikan dengan time (waktu). Pendataan dilakukan sebelum dan sesudah kerja pada Periode I dan Periode II terhadap 14 sampel selama 10 (sepuluh) hari. Data yang diperoleh dianalisis dengan paired t-test pada taraf signifikansi 5\%. Hasil penelitian menunjukkan bahwa perbaikan mekanisme kerja berorientasi ergonomi mengurangi keluhan muskuloskeletal pekerja pembuat piranti upakara sebesar 44,45\%, mengurangi stres kerja pekerja pembuat piranti upakara sebesar 29,90\%, dan meningkatkan produktivitas pekerja pembuat piranti upakara sebesar 53,93\%. Dengan demikian dapat disimpulkan bahwa perbaikan mekanisme kerja berorientasi ergonomi dapat mengurangi keluhan muskuloskeletal dan stres kerja serta meningkatkan produktivitas pekerja pembuat piranti upakara.

Kata kunci: mekanisme kerja ergonomi, ergonomi, piranti upakara

\section{INTRODUCTION}

Home industries have an important role in the Indonesian economy such as to reduce unemployment. Home industries can develop because they still use a local resource such as local human resources, local raw materials, and local equipment. Home industries of piranti upakara makers have progress rapidly especially in Bali. Balinese women spend more time in their work until they decide to buy ceremonial equipment. The working mechanism of piranti upakara makers in Peliatan Village involves physical activities. The working mechanism has the potential to cause musculoskeletal disorder, fatigue, and the feasibility of work accidents.

Work mechanism is a combination of several work processes involving several workers in the work cycle (Sutajaya, 2018). Conducive work mechanism will improve quality products and the quality of a worker's health (Manuaba, 2003). Conducive work mechanism refers to ergonomic principles (Manuaba, 2003; Hsieh, et al., 2013; Agyemang, et al., 2014). Work system of piranti upakara makers without ergonomic principles. Ergonomic problems of workers piranti upakara makers such as (a) complex of workload demands due to the large orders of ceremonial equipment; (b) workstations incompatible with anthropometry causes non-physiological position and posture of work; (c) muscle overuse due to non-physiological position and posture of work; and (d) static motion is dominated in the work. These problems resulted in: (a) work stress due to complex workload and working intense conditions; (b) uncomfortable working; (c) fatigue occurs more quickly; (d) more mistake in work; (e) increase workload; (f) energy required for the same cooperative effort is higher; (g) cause musculoskeletal disorders especially in the musculoskeletal system; and (h) reduce productivity (Sutajaya, 2018).

Improvement condition of work should use systemic, holistic, interdisciplinary, and participatory (SHIP) approach, so that workplaces and work processes are designed to be technically suitable for workers and physiology does not result in too heavy a workload. These conditions can avoid the emergence of work stress, do not cause musculoskeletal disorders, decrease fatigue of work, and increase job satisfaction (Bahari, et al., 2013; Tanjung, 2015; Mokaya, et al., 2013). The working mechanism of workers piranti upakara makers consist of three parts: (a) the process of making jaja upakara; (b) the process of making jejahitan; and (c) the process of metanding piranti upakara. The process of making jaja upakara consists of milling the flour, shaping, and frying then ready to be assembled during the metanding process. The process of making jejahitan consists of cutting the leaves, assembling, and ready to assemble during the metanding process. The metanding process is a combination of several materials such as flowers, jejahitan, and jaja upakara to form a piranti upakara (offerings). The work process is carried out sequentially to produce the piranti upakara.

The working mechanism of piranti upakara makers is usually carried out every day in a monotonous condition. The complex workload due to the large order of piranti upakara also 
causes fatigue to piranti upakara makers. Workers generally do one job only, so it becomes monotonous. Static motions are often performed in the process of making jaja upakara, making jejahitan, and metanding piranti upakara. The static motion means a sitting or standing position with more than two or three hours of duration. The process of making jaja upakara and making jejahitan usually takes more than two hours. Meanwhile, the process of metanding piranti upakara usually takes more than three hours. If it is not corrected immediately, various complaints will arise such as musculoskeletal disorders, increased fatigue, workload, and work stress due to monotonous work.

Based on the results of a preliminary study to 12 workers piranti upakara makers in Peliatan Village, Ubud, Gianyar, Bali there were musculoskeletal disorders of workers increase to $39.72 \%$, the work stress of workers increases to $46.66 \%$, and the workload of workers increase to $16.49 \%$. The workload of workers who made jaja upakara increase to $16.09 \%$, the workload of workers who made jejahitan increase to $15.94 \%$, and the workload of workers who made piranti upakara increase to $17.41 \%$. Work organization (remuneration system, work methods, and work processes), work instrument (work tools, work stations, personal protective equipment), characteristics of worker (age, male gender, weight, height, health, anthropometry), and environmental factors (temperature, relative humidity, lighting intensity, wind speed, noise) also affect musculoskeletal disorders of workers and stress due to the work of piranti upakara makers.

Apart from monotonous work, workers also work in the wrong position and posture. Workers sit with their waist twisted and their legs hanging for more than two hours on the house floor's edge. This work methods causes non-physiological posture such as (1) the muscles that work statically due to unchanged (static) work posture for more than two hours; (2) forward inclination of the neck and head due to the low work station and not using the worktable; (3) bent posture due to the low work station and not using the worktable; (4) hanging legs due to the seat too high $(48.00 \mathrm{~cm})$, so that it is not in accordance with anthropometry of the popliteal height in 5 percentile $(43.00 \mathrm{~cm})$; (5) twisting posture effect in differences of the load on both sides on the spine. Related to this research, Sutajaya (2018) explains that the wrong posture in work methods such as static posture, repeated circular, and bowing motions can affect musculoskeletal disorders. Monotonous work with a demanding workload such as the large order of piranti upakara can trigger stress on workers.

To improve the working mechanism of piranti upakara makers which does not refer to ergonomic principles, necessary to (a) repair work stations to improve non-physiological work posture; (b) providing seats for majejahitan activities and making jaja upakara activities; (c) changing the work system from static to dynamic. That improve it should be done so that workers are always safe, comfortable, healthy, and free from the stressful condition. So that workers can increase productivity. Ergonomic improvement should be considered with local wisdom. Ergonomic principles that prioritize comfort, health, safety, efficiency, effectiveness, and productivity are closely related to the Tri Hita Karana. In addition, the concept of desa kala patra also to be a reference to improving working conditions in home industries.

The applied of Tri Hita Karana in this research are (1) praying before working as a being devotion to God; (2) discarding unused ceremony facilities in their place as a being to preserving the environment; (3) keep the relationships between workers in the workplace as a being of love with others. This research also refers to desa (place), kala (time), patra (habit) such as (1) workers must use cloth (kamen) when making piranti upakara; (2) workers come from the local village to avoid differences perceptions how to made of piranti upakara. This concept is useful for the success of an ergonomic intervention in an area (Sutajaya \& Ristiati, 2011).

Problem formulation can be made based on the background are (a) does improvement mechanism of work oriented by ergonomic reducing musculoskeletal disorder of piranti 
upakara makers? (b) does improvement mechanism of work oriented by ergonomic reducing work stress of piranti upakara makers? (c) does improvement mechanism of work oriented by ergonomic increase the productivity of piranti upakara makers?

\section{METHOD}

This research was inspected by quasi-experimental with the same subject design (treatment by subject design) and randomized pre and posttest group design. The subjects in this research are workers who made piranti upakara in Peliatan Village, Ubud District, Gianyar Regency, Bali Province. The target population in this study is all workers who made piranti upakara in Peliatan Village. The accessible population is all workers who made piranti upakara spread over in 10 banjar that fulfil the inclusion criteria. The sample in this study is all workers piranti upakara makers who selected in determining the number of samples and were involved in this study. The number of samples involved in this study is 14 people of workers piranti upakara in randomly selected stratified (multistage random sampling).

The independent variable in this study is the improvement mechanism of work oriented by ergonomic. The improvement mechanism of work such as (a) repair of work stations for standing position by adding the height of the table $(19 \mathrm{~cm})$ and adding the height of the table $(18 \mathrm{~cm}$ ) for sitting position; (b) providing seats for majejahitan activities and making jaja upakara activities; (c) changing a static work system to dynamic system with job rotation. Repairing work station for standing, according to the height of the table for light work must be reduced by $5 \mathrm{~cm}$ from elbow height in the 5 th percentile standing position. Therefore, the height measurement of metanding table (standing position) was added from $69 \mathrm{~cm}$ to $88 \mathrm{~cm}$. For majejahitan and making jaja upakara activities (sitting position) were added from $48 \mathrm{~cm}$ to 66 $\mathrm{cm}$. It was obtained from the addition of elbow height on sitting position in the 5th percentile $(21 \mathrm{~cm})$ with seat height $(45 \mathrm{~cm})$.

Dependent variables in this study are musculoskeletal disorders was recorded by Nordic Body Map Questionnaire, work stress was recorded by the Work Stress Questionnaire, and productivity assessed based on output (product produce) divided by input (pulse) multiplied by time. Control variables are (a) subject characteristics (age, weight, height, sex, health status, and work experience); (b) work organization (organization structure, remuneration system, and nutrition); (c) instruments (work tools and personal protective equipment); (d) environmental conditions at work (temperature, relative humidity, lighting intensity, wind speed, and noise). Data collection is carried out before and after work in Period I (without intervention) and Period II (with intervention) for ten days. Data collection in Period I is carried out for 3 three days then followed by one day of washing out period, three days of adaptation, and data collection in Period II is also carried out for 3 three days.

The data obtained were analyzed by (a) characteristics subject data were analyzed descriptively by calculating mean and standard deviation; (b) environmental conditions data were analyzed descriptively by calculating mean and standard deviations then followed by paired t-test to determine the comparability of environmental conditions in Period I and Period II; (c) the worker's anthropometric data were analyzed using the 5th and 50th percentile tests; (d) the data musculoskeletal disorders, work stress, and productivity were analyzed by paired t-test at a significance level of $5 \%$.

\section{RESULTS AND DISCUSSION}

The result of environmental conditions data analysis between Period I and Period II showed in Table 1. 
Table 1

The Result of Environmental Conditions Data Analysis

\begin{tabular}{lcccccc}
\hline \multirow{2}{*}{ Variable } & \multicolumn{2}{c}{ Period I } & \multicolumn{2}{c}{ Period II } & \multirow{2}{*}{$\mathrm{p}$} \\
\cline { 2 - 5 } & Mean & SD & Mean & SD & & \\
\hline Dry Temperature $\left({ }^{\circ} \mathrm{C}\right)$ & 30.07 & 1.308 & 30.26 & 1.483 & 1.053 & 0.323 \\
Wet Temperature $\left({ }^{\circ} \mathrm{C}\right)$ & 27.22 & 1.787 & 27.46 & 1.272 & 0.852 & 0.419 \\
Relative Humidity (\%) & 74.04 & 7.402 & 75.79 & 8.079 & 0.856 & 0.417 \\
Light Intensity (lux) & 580.78 & 101.092 & 564.11 & 86.693 & 1.200 & 0.265 \\
Wind Speed (m/s) & 0.17 & 0.063 & 0.17 & 0.061 & 0.503 & 0.629 \\
Noise dB(A) & 60.16 & 3.091 & 60.37 & 3.132 & 0.433 & 0.677 \\
\hline
\end{tabular}

Dry temperature, wet temperature, relative humidity, light intensity, wind speed, and noise were measured in this research. The environmental conditions between Period I and Period II are comparable ( $\mathrm{>}>0.05)$. Environmental conditions in this research have the same effect on determining changes in worker's health conditions. Musculoskeletal disorders, work stress, and productivity changes are fully influenced by the improvement mechanism of work oriented by ergonomic.

Result of the hypothesis on musculoskeletal disorders between before and after working in Period I and Period II showed in Table 2.

Table 2

Result of the Hypothesis on Musculoskeletal Disorders

\begin{tabular}{lcccccc}
\hline \multirow{2}{*}{ Variable } & \multicolumn{2}{c}{ Period I } & \multicolumn{2}{c}{ Period II } & \multirow{2}{*}{ t } & $\mathrm{p}$ \\
\cline { 2 - 5 } & Mean & SD & Mean & SD & & \\
\hline $\begin{array}{l}\text { Musculoskeletal } \\
\begin{array}{l}\text { Disorders } \\
\text { (Before Working) }\end{array}\end{array}$ & 29.52 & 0.884 & 30.00 & 1.922 & 0.990 & 0.340 \\
$\begin{array}{l}\text { Musculoskeletal } \\
\text { Disorders } \\
\text { (After Working) }\end{array}$ & 58.58 & 2.829 & 32.54 & 1.461 & 30.593 & $\begin{array}{c}0.000 \\
1\end{array}$ \\
\hline
\end{tabular}

Based on Table 2 it was revealed that musculoskeletal disorders of workers piranti upakara makers have decreased between Period I and Period II by $44.45 \%$. That showed the mechanism of work oriented by ergonomic can improve the health of workers. It showed on musculoskeletal disorders of the workers piranti upakara makers were reduced. This research can be used as a reference to explain that the mechanism of work without ergonomic design must be improved with ergonomic design. It can be spared of musculoskeletal disorders as an effect of improper technology transfer. The mechanism of work without ergonomic design result in (1) statically motion due to working posture has not changed for more than two hours; (2) forward inclination of the neck-head and bending posture due to the low work station and not using the worktable; (3) hanging legs due to the seat too high; and (4) asymmetrical posture (twisting). 
The workers with activities to make jejahitan and jaja upakara in a sitting position for more than two hours. It showed in the mechanism of work without an ergonomic design. The work tools and materials will be placed by a worker near their workplaces when the activity started. Worker's health is also compounded by non-physiological position and posture of work. The activities of making jejahitan and jaja upakara are carried out in a bent sitting position due to not using the worktable. The worker's hips also twisted due to sitting on the edge of the floor. The same thing happens to metanding activities. Workers are in a standing position for more than three hours. Metanding activities carried out in a standing position with bent work posture. It happens because the worktable is too low. It can increase the risk of musculoskeletal disorders.

Grandjean (2007) explains that forced posture for too long can increase the workload on the musculoskeletal system. So that it has a negative impact on health. A forced posture will attack the muscle so that causing stretching and pressure on the tendons, nerves, and blood vessels. It can cause inhibiting blood circulation to the active muscles and increasing the accumulation of lactic acid and body temperature. This problem can cause muscle fatigue which is felt as muscle pain. Biomechanically, the further apart of the limbs from the fulcrum it can cause the greater of force produced. So that the muscles contract more strongly to produce more force. If the muscles contract more strongly, the muscle tends will lose a lot of energy to contracting again.

This research was in accordance with other researchers such as (a) Purnamawati (2013) explained that ergonomic interventions in the process of making banten ngaben pranawa reduce musculoskeletal disorders to 37.98\%; (b) Dinata, et al. (2013) revealed that the alternating sitting-standing posture reduced musculoskeletal disorders of ironing women worker in household to $13.15 \%$; (c) Putri \& Griadhi (2015) explained that repairing the workstation for wood carving reduced electrical activity of the trapezius muscle to $17.44 \%$ and the electrical activity of the erector spinae muscles to $12.28 \%$; (d) Mindhayani \& Purnomo (2016) explained that improving the work system with ergonomic approach reduced musculoskeletal disorders to $10.91 \%$; (e) Rosanti \& Wulandari (2016) revealed that repairing work chairs for tailors reduced musculoskeletal disorders to 36.6\%; (f) Ferdyastari, et al. (2018) explain that workstation improvement and stretching for employee in the silver industry reduced musculoskeletal disorders to 21.61\%; (g) Dhari (2019) explained that providing active recovery for pembatik cap reduced musculoskeletal disorders to $31.6 \%$.

Result of the hypothesis on work stress between before and after work in Period I and Period II showed in Table 3.

Table 3

Result of the Hypothesis on Work Stress

\begin{tabular}{lcccccc}
\hline \multirow{2}{*}{ Variable } & \multicolumn{2}{c}{ Period I } & \multicolumn{2}{c}{ Period II } & \multirow{2}{*}{ t } & $\mathrm{p}$ \\
\cline { 2 - 5 } & Mean & SD & Mean & SD & & \\
\hline $\begin{array}{l}\text { Work Stress } \\
\text { (Before Working) }\end{array}$ & 41.24 & 1.610 & 41.68 & 1.231 & 0.777 & 0.451 \\
$\begin{array}{l}\text { Work Stress } \\
\text { (After Working) }\end{array}$ & 86.28 & 2.737 & 60.48 & 1.260 & 36.144 & 0.0001 \\
\hline
\end{tabular}

In this research, the mechanism of work oriented by ergonomic was improved. So that workers are always safe, healthy, comfortable, free from work stress, and increase productivity. The mechanism of work oriented by ergonomic was able to reduce work stress by $29.90 \%$ between 
Period I and Period II. This shows that the mechanism of work oriented by ergonomic can improve worker's health. It showed on work stress of the workers piranti upakara makers are reducing.

The monotonous process of making jaja upakara, making jejahitan, and metanding happened for more than three hours. The workers have to do these activities every day without getting enough rest. It is due to the large orders of ceremonial equipment. If it is not corrected immediately, various complaints will arise such as musculoskeletal disorders, increased fatigue, workload, and psychological disorders especially work stress. Widyastuti (2017) explains that stress is a disorder in which the body overproduces stress hormones such as cortisol. The brain responds to high levels of cortisol as an external threat that needs to be fought or avoided (fight or flight response). To prevent running out of energy, the brain will order the body to take a rest. If workers continue to work, it can cause muscle fatigue.

Bachroni \& Asnawi (2015) explain that work stress sources are the workload that is too light or too heavy and time pressure when doing the job. Work stress also arises from the inability to control an uncertain or unpredictable situation. The types of workers who are prone to stress are workers who have an obsession with time because they want to finish the work. This happens to workers piranti upakara makers with high demand for orders. When orders for ceremonial equipment boomed, workers would be pressed the time to complete these orders.

The work of making piranti upakara is one of the most complex jobs. So that it is required to have adequate expertise. The work is considered complicated so that workers tend to get frustrated and stressed out quickly. Stress on workers will cause various physical and emotional reactions. Emotional reactions that often occur in piranti upakara workers are anger and fear. Musculoskeletal disorder is one of the physical reactions in work stress. Related to this research, the mechanism of work oriented by ergonomic was improved. The improvement mechanism of work there are (1) repairing work stations; (2) providing seats for workers with majejahitan activities and making jaja upakara; (3) and changing the static work system to dynamic. Improved work mechanisms will increase work comfort and reduce work stress due to boredom caused by monotonous working.

This research is synergized with other researchers such as (a) Sutrisno (2010) revealed that the contribution of organizational culture, work stress, and commitment to employee performance is $83.50 \%$; (b) Purnawati (2014) explained that an ideal work stress management program includes primary, secondary, and tertiary prevention refers to the workers and employer's need; (c) Noor, et al. (2016) explained that workers must be free from stressful conditions because job stress and job satisfaction have a simultaneous and significant effect on employee performance; (d) Susetyo \& Ratnaningsih (2016) explained that the perception of $\mathrm{K} 3 \mathrm{had}$ an effective effect of $13.6 \%$ on the work stress of production employees; (e) Wartono (2017) explained that job stress affects magazine employee performance by $77.44 \%$.

Result of the hypothesis on productivity in Period I and Period II showed in Table 4.

Table 4

Result of the Hypothesis on Productivity

\begin{tabular}{cccccccc}
\hline \multirow{2}{*}{ Variable } & \multicolumn{2}{c}{ Period I } & \multicolumn{2}{c}{ Period II } & \multirow{2}{*}{ t } & p \\
\cline { 2 - 5 } & Mean & SD & Mean & SD & & \\
\hline Productivity & 26.12 & 0.949 & 40.73 & 0.816 & & 47.853 & 0.0001 \\
\hline
\end{tabular}

Based on Table 4, it was found that productivity increased by $55.93 \%$ between Period I and Period II. It shows that improving mechanism of work oriented ergonomic make workers 
more safe, healthy, and comfortable so that productivity will increase. It showed that improvement mechanism of work oriented by ergonomic can reduce musculoskeletal disorders to $44.45 \%$, reduce work stress to $29.90 \%$, and consequently increase the productivity to $53.93 \%$.

Productivity measurement has an important role to determine the suitability between work productivity and the productivity were expected. Improvement mechanism of work with ergonomic principles are able to increase productivity of workers such as (a) good organized make the work is easier; (b) improvement the mechanism of work oriented by ergonomic principle can decrease musculoskeletal disorders, work stress, and workload so that a larger number of result are obtained with the best quality; (c) improvement the mechanism of work oriented by ergonomic principle can produce more products; (d) efficient use of raw materials and equipment that is not too expensive without reducing the quality of product.

This research is in accordance with other researchers such as (a) Purnamawati (2013) explained that ergonomic interventions in the process of making banten ngaben pranawa are able to increase the productivity by 78\%; (b) Mindhayani \& Purnomo (2016) revealed that improving the work system with a macro ergonomic approach was able to increase employee productivity by $36.96 \%$; (c) Sutajaya (2019) explained that improving condition of work based on local wisdom with ergonomic principle increased productivity of sculptors by $14.85 \%$; and (d) Nooryana, et al. (2019) explained that dynamic stretching exercises and active rest were able to increase the productivity of garment industry workers by $31.25 \%$.

\section{CONCLUSION}

The conclusion that improvement mechanism of ergonomic work oriented reducing musculoskeletal disorders of workers to $44.45 \%$, reducing the work stress of workers to $29.90 \%$, and increasing the productivity of workers to $53.93 \%$.

The suggestions of this study are: (a) to the workers of piranti upakara makers should use the mechanism of ergonomic work oriented; (b) to the employer of piranti upakara makers should always pay attention of the work mechanism who at risk for health; (c) to village authority should facilitate the efforts of work mechanism improvement in home industries, particularly those making ceremonial equipment.

\section{REFERENCES}

Agyemang, C. B., Nyanyofio, J. G., and Gyamfi, G. D. 2014. Job, Stress, Sector of Work, and Shift-Work Pattern as Correlates of Worker Health and Safety: A Study of a Manufacturing Company in Ghana. International Journal of Business and Management. Vol. 9(7):53-59.

Bachroni, M., and Asnawi, S. 2015. Stres Kerja. Buletin Psikologi. Vol. 7(2):28-39.

Bahari, Salim, J., and Susihono, W. 2013. Perbaikan Postur Kerja dengan Pendekatan Metode RULA dan NIOSH di Bagian Produksi Mixer. Jurnal Teknik Industri. Vol. 1(1):77-87.

Dhari, I. F. W. 2019. Pemberian Istirahat Aktif dan Pilates Exercise Menurunkan Keluhan Muskuloskeletal Pada Pembatik Cap di Industri Batik. Jurnal Fisioterapi dan Rehabilitasi. Vol. 3(1):38.

Dinata, I. M. K., Adiputra, N., and Adiatmika, I. P. G. 2013. Sikap Kerja Duduk-Berdiri Bergantian Menurunkan Kelelahan, Keluhan Muskuloskeletal Serta Meningkatkan Produktivitas Kerja Penyetrika Wanita di Rumah Tangga. Jurnal Ergonomi Indonesia. Vol. 1(1):38.

Ferdyastari, N., Adiatmika, I. P. G., and Purnawati, S. 2018. Workstation Improvement dan Pemberian Stretching Karyawan Pembersihan Injeksi Menurunkan Kebosanan Kerja, 
Keluhan Muskuloskeletal, dan Meningkatkan Produktivitas Pada Industri Perak di CV JPS. Jurnal Ergonomi Indonesia. Vol. 4(1):26.

Grandjean, E. 2007. Fitting the task to the Man. A Textbook of Occupational Ergonomis. 4th Edition. London: Taylor \& Francis.

Grandjean, E., and Kroemer. 2000. Fitting the Task to the Human. A Textbook of Occupational Ergonomics. 5th Edition. Piladelphie: Taylor \& Francis.

Hsieh, Y., Apostolopoulos, Y., and Sonmez, S. 2013. World at Work: Hotel Cleanerss. Occupational and Environmental Medicine Journal. Vol. 70(5):360-364.

Manuaba, A. 2003. "Penerapan Ergonomi Meningkatkan Produktivitas" (makalah). Denpasar: Bagian Ilmu Faal Fakultas Kedokteran Universitas Udayana.

Mindhayani, I., and Purnomo, H. 2016. Perbaikan Sistem Kerja Untuk Meningkatkan Produktivitas Karyawan. Jurnal Penelitian dan Aplikasi Sistem dan Teknik Industri. Vol. 10(1):105.

Mokaya, S. O., Nyangara, D. M., and James, L. T. 2013. The Effect of Dividend Policy on Market Value in the Banking Industry: The Case of National Bank Kenya. International Journal of Arts and Commerce. Vol. 2(1):91-101.

Noor, N. N., Rahardjo, K., and Ruhana, I. 2016. Pengaruh Stres Kerja dan Kepuasan Kerja Terhadap Kinerja Karyawan (Studi Pada Karyawan PT. Jasa Raharja (Persero) Cabang Jawa Timur di Surabaya). Jurnal Administrasi Bisnis. Vol. 31(1):14.

Nooryana, S., Adiatmika, I. P. G., and Purnawati, S. 2019. Latihan Peregangan Dinamis dan Istirahat Aktif Menurunkan Beban Kerja dan Meningkatkan Produktivitas Pada Pekerja di Industri Garmen Adhi Fashion. Seminar Nasional Hasil Penelitian dan Pengabdian pada Masyarakat IV Tahun 2019. Universitas Muhammadiyah Purwokerto.

Pheasant, S. 1991. Ergonomics Work and Health. London: Macmillan Academic Profesional Ltd.

Purnamawati, M.S.P. 2013. "Intervensi Ergonomi Meningkatkan Efisiensi Pekerja pada Proses Pembuatan Banten Upacara Ngaben Pranawa di Kota Denpasar" (disertasi). Universitas Udayana.

Purnawati, S. 2014. Program Manajemen Stres Kerja di Perusahaan: Sebuah Petunjuk Untuk Menerapkannya. Buletin Psikologi Fakultas Psikologi Universitas Gajah Mada. Vol. 22(1):36-44.

Putri, P. D. W., and Griadhi, I. P. A. 2015. Perbaikan Stasiun Kerja Menurunkan Aktivitas Listrik Otot dan Keluhan Muskuloskeletal Pada Perajin Ukir Kayu di Desa Batuan Gianyar Bali. E-Journal Medika Udayana. Vol. 4(8):1-2.

Rosanti, E., and Wulandari, D. 2016. Pengaruh Perbaikan Kursi Kerja Terhadap Keluhan Muskuloskeletal Pada Pekerjaan Menjahit di Desa X. Journal of Industrial Hygiene and Occupational Health. Vol. 1(1):38.

Susetyo, R. I., and Ratnaningsih, I. Z. 2016. Persepsi Terhadap Keselamatan dan Kesehatan Kerja dan Stres Kerja Pada Karyawan Bagian Produksi PT. X di Bekasi. Jurnal Empati. Vol. 5(1):55-59.

Sutajaya, I. M. 2018. Ergonomi. Depok: PT. Raja Grafindo Persada.

Sutajaya, I. M. 2019. Ergonomi Pendidikan. Yogyakarta: Media Akademi.

Sutajaya, I. M., and Ristiati, N. P. 2011. Perbaikan Kondisi Kerja Berbasis Kearifan Lokal yang Relevan dengan Konsep Ergonomi untuk Meningkatkan Kualitas Kesehatan dan Produktivitas Pematung di Desa Peliatan Ubud Gianyar. Jurnal Penelitian dan Pengembangan Sains dan Humaniora. Vol. 5(3):1-2.

Sutrisno, H. E. 2010. Pengaruh Budaya Organisasi, Stres Kerja, dan Komitmen Terhadap Kinerja Karyawan CV. Bintang Karya Putra di Surabaya. Jurnal Ekonomi dan Keuangan. Vol. 14(4):474. 
Tanjung, S. 2015. Analisis Postur Kerja untuk Mengurangi Risiko Muskuloskeletal Disorders Menggunakan Metode Rapid Upper Limb Assessment (RULA). Jurnal Ilmiah Universitas Bakrie. Vol. 3(3):7.

Wartono, T. 2017. Pengaruh Stres Kerja Terhadap Kinerja Karyawan (Studi Pada Karyawan Majalah Mother and Baby). Jurnal Ilmiah Prodi Manajemen Universitas Pamulang. Vol. 4(2): 13 .

Widyastuti, A. D. 2017. Hubungan Stres Kerja Dengan Kelelahan Kerja Pada Pekerja Area Workshop Konstruksi Box Truck. The Indonesian Journal of Occupational Safety and Health. Vol. 6(2):1. 